\title{
UPAYA MENINGKATKAN KARAKTER RASA INGIN TAHU DI SMP NEGERI 1 MUARO JAMBI
}

\author{
Yohana Liando Tiarma Sihotang \\ Fakultas Keguruan dan Ilmu Pendidikan (FKIP), Universitas Jambi \\ Mendalo Darat, Jambi Luar Kota, Muaro Jambi Regency, Jambi 36657 \\ e-mail: yohanasihotang1401@gmail.com
}

\begin{abstract}
Abstrak
Pendidikan adalah segala situasi hidup yang mempengaruhi individu. Penelitian ini bertujuan untuk mengetahui apakah SMP Negeri 1 Muaro Jambi memiliki rasa ingin tau yang tinggi atau tidak sama sekali. Penelitian ini menggunakan sistem survey sehingga dalam sistem tersebut, kita dapat mengetahui hasil yang akan kita dapatkan dari penelitian ini. Hasil yang didapatkan ternyata sangatlah kuat sehingga dapat disimpulkan SMP Negeri 1 Muaro Jambi mempunyai rasa ingin tau yang tinggi. Dalam mengupayahkan karakter rasa ingin tahu pada siswa kita harus mengetahui sifat dan hal hal apa saja yang diminatin pada siswa tersebut. Suatu emosi yang berkaitan dengan perilaku ingin tahu seperti eksplorasi, investigasi, dan belajar, terbukti dengan pengamatan pada manusia. Istilah ini juga dapat digunakan untuk menunjukkan perilaku itu sendiri disebabkan oleh emosi rasa ingin tahu. Untuk meningkatkan rasa ingin tahu siswa lebih banyak antusias untuk mencoba berbagai hal. Siswa yang telah menginjak remaja, ketertarikan atau rasa ingin tahu anak Anda masihlah ada. Rasa ingin tahu itu belum sepenuhnya lenyap. Hanya saja, saat ia beranjak remaja, rasa ingin tahunya sangat terbatas. Ia hanya penasaran terhadap hal-hal yang menyangkut seksualitas dan lawan jenis. Sementara itu, ketertarikannya terhadap hal lain seolah melenyap.
\end{abstract}

Kata Kunci:

karakter, angket, rasa ingin tahu ,kuantitatif, korelasi

\begin{abstract}
Education is all life situations that affect individuals. Muaro Jambi Public Middle School 1 has a high curiosity or not at all. This research uses a survey system so that in this system, we can get the results that we will get from this research. The results obtained turned out to be very beneficial for SMP Negeri 1 Muaro Jambi, having a high curiosity. In seeking the character of curiosity in students we must know the nature and things that are reduced in these students, every conversation related to curiosity such as inquiry, investigation, and learning, is proven by using human animal. This term can also be used to indicate the relationship itself caused by curiosity. To increase the curiosity of more students to try various things. Students who have been teenagers, are interested or want to know your child is still there. Curiosity has not completely disappeared. It's just that, when he was a teenager, his curiosity was very limited. He is only curious about the things that choose sexuality and the opposite sex. Meanwhile, his interest in other things seemed to disappear.
\end{abstract}

Keyword:

character, questionnaire, curiosity, quantitative, correlation

\section{A. PENDAHULUAN}

Rasa ingin tau itu sangat lah berperan penting apalagi di era millenials sekarang ini. Anak sekarang lebih mempedulikan kesenangan pribadi mereka dibandingkan membuka buku atau informasi yang dapat menambah ilmu pengetahuan mereka. Untuk itu dengan penelitian ini kita dapat mengetahui apakah masih ada siswa siswi yang mempunyai karakter Rasa Ingin Tau yang tinggi atau tidak. Pendidikan merupakan bagian penting dalam proses pembangunan nasional khususnya pembangunan manusia. Dengan pendidikan yang berkualitas diharapkan akan lahir manusia-manusia yang berkualitas yang mampu untuk melakukan perubahan-perubahan kearah yang lebih baik. Salah satu upaya pemerintah untuk mencapai keberhasilan pendidikan nasional yang dengan membentuk kurikulum. Penilaian dalam sistem pembelajaran berfungsi sebagai cara untuk menilai keberhasilan proses dan hasil belajar peserta didik. Penilaian hasil belajar bertujuan untuk mengukur tingkat ketercapaian kompetensi peserta didik. Proses pembelajaran IPA melibatkan berbagai aktivitas antara guru dan peserta didik dalam mendapatkan pengetahuan, membentuk sikap ilmiah maupun mengembangkan keterampilan sebagai aspek penting dalam kecakapan hidup. Salah satu sikap ilmiah yang penting untuk dikembangkan dalam Kurikulum 2013 yaitu rasa 
ingin tahu(Fithriyyati \& Maryani, 2018). Ketika peserta didik memiliki rasa ingin tahu yang tinggi, mereka berusaha untuk memahami,mengeksplorasi, serta menganalisis berbagai fenomena, gejala, dan peristiwa alam termasuk fenomena alam di sekitarnya. Hal itu dapat membantu peserta didik untuk mengasah pemahaman, menghubungkan informasi lama dan baru diperoleh, serta melatih berpikir kritis.

Sebagai investasi utama maka pendidikan perlu mengasah rasa ingin tahu. Rasa ingin tahu pada setiap orang amatlah penting. Semua pemikir besar adalah orang-orang dengan karakter penuh rasa ingin tahu. Sebut saja Newton, Thomas Alva Edison, Albert Einstein, Leonardo Da Vinci, adalah orang-orang besar yang hidup dengan rasa ingin tahu. Tentunya dalam pelaksanaan pendidikan saat ini menginginkan siswa-siswanya sebagai pemikir-pemikir besar di masa depan. Rasa ingin tahu itu penting dalam pembelajaran. 1) Rasa ingin tahu membuat pikiran siswa menjadi aktif. 2) Rasa ingin tahu membuat siswa menjadi para pengamat yang aktif. 3) Rasa ingin tahu akan membuka dunia-dunia baru yang memantang dan menarik siswa untuk mempelajarinya lebih dalam. 4) Rasa ingin tahu membawa kejutan-kejutan kepuasan dalam diri siswa, dan meniadakan rasa bosan untuk belajar.

Masalah utama dalam pendidikan di Indonesia adalah rendahnya hasil belajar siswa di sekolah. Dalam konteks pendidikan Fisika, sebagai contoh, hasil belajar dimaksud tidak hanya pada aspek kemampuan mengerti Fisika sebagai Ilmu Pengetahuan Alam atau cognitive tetapi juga aspek sikap atau attitude terhadap Fisika. Suhardi (2012:6) menyatakan bahwa, "Pendidikan di sekolah merupakan kelanjutan pendidikan dalam keluarga. Dan pendidikan ini dilaksanakan secara mandiri dimana anak-anak tidak lagi dilayani oleh orang tuannya, akan tetapi pendidikan di sekolah dibawah pengawasan guru". Lingkungan belajar di sekolah yang kondusif dan tenang dapat juga mejadi salah satu faktor yang mempengaruhi minat dan ketertarika siswa dalam pelajaran fisika, lingkungan demikian dibutuhkan karena pelajaran fisika membutuhkan ketelitian dan kefokusan yang tinggi agar apa yang dipelajari siswa dapat diserap dan dipahami, sehingga dapat memudahkan siswa dalam mencapai hasil belajar yang lebih baik lagi.
Belajar merupakan suatu proses perubahan prilaku akibat suatu pengalaman (Garge yang dikutip Syah (1995)). Sedangkan Morgan yang dikutip oleh Syah (1995) menyebutkan bahwa: Suatu kegiatan dikatakan belajar apabila memiliki tiga ciri yaitu : 1) belajar adalah perubahan. 2) perubahan terjadi karena latihan dan pengalaman, bukan karena pertumbuhan. 3) perubahan tersebut harus bersifat permanen dan tetap ada untuk waktu yang cukup lama. Kegiatan dan usaha yang mengakibatkan suatu perubahan tingkah laku itu merupakan proses belajar. Sedangkan perubahan tingkah laku sendiri merupakan hasil belajar. Perubahan tingkah laku dalam belajar terjadi setelah interaksi dengan sumber belajar. Sumbersumber belajar yang disebutkan dapat berupa buku, lingkungan, guru atau sesama teman.Minat belajar sebagai salah satu faktor yang sangat menentukan hasil belajar siswa untuk mempelajari sesuatu yang dipelajarinya, seperti yagn dikemukakan oleh Juhri (2006 : 96) menyebutkan "minat dalam pendidikan adalah suatu kekuatan yang membuat peserta didik memiliki rasa ketertarikan kepada pelajaran. Pendapat di atas memiliki arti jika seseorang memiliki rasa keterkaitan maka ia akan melakukan sesuatu hal yang menariknya tersebut dalam hal ini adalah ketertarikan dalam belajar yang baik dan karena minat ini maka intensitas untuk belajar akan bertambah tapi hal ini akan berlaku sebaiknya yaitu dapat mengurangi intensitas belajar. Menurut Oemar Hamalik (2004) menyatakan bahwa "hasil belajar akan tempat terjadinya perubahan tingkah laku pada diri seseorang yang dapat diamati dan diukur dalam perubahan pengetahuan sikap dan keterampilan". Dari pengertian tersebut dapat diambil pengertian bahwa hasil belajar adalah suatu perubahan tingkah laku seseorang yang terjadi karena telah melakukan serangkaian kegiatan belajar, sehingga akan bertambah perilakunya.

Dalam teknik pengumpulan data dan instrument pengumpul data merupakan faktor penting demi keberhasilan penelitian. Hal ini berkaitan dengan bagaimana cara mengumpulkan data, siapa sumbernya, dan alat apa yang digunakan. Metode pengumpulan data merujuk pada suatu cara sehingga dapat diperlihatkan penggunanya melalui angket/kuesioner, wawancara dan observasi, tes dokumentasi dan sebagainya. Penelitian ini penulis membutuhkan sebuah objek atau subjek 
agar masalah dapat terpecahkan. Populasi merupakan objek dalam penelitian ini dengan menentukan populasi maka peneliti akan mampu melakukan pengolahan data. Untuk mempermudah pengolahan data maka penulis akan mengambil bagian dari jumlah dan karakteristik yang dimiliki oleh populasi yang disebut sampel. Menurut Sugiyono (2014: 81) berpendapat sample adalah bagian dari jumlah dan karakteristik yang dimiliki oleh populasi tersebut. Sampel dilakukan karena peneliti memiliki keterbatasan dalam melakukan penelitian baik dari segi waktu, tenaga, dana dan jumlah populasi yang sangat banyak. Maka peneliti harus mengambil sampel yang benar-benar representative (dapat mewakili).

Pada kenyataannya masih banyak guru yang tidak memperhatikan proses pembelajaran yang sesuai dengan Permendikbud No. 65 tahun 2013. Berdasarkan pengamatan banyak guru yang menggunakan pembelajaran konvensional. Pembelajaran konvesional yaitu guru menjelaskan, guru memberikan contoh, guru memberikan soal latihan dan guru memberikan tugas. Pola pembelajaran yang seperti ini akan mengurangi kebermaknaan dan pengalaman yang diperoleh siswa. Hal di atas terindikasi juga dalam proses pembelajaran matematika yang dilakukan oleh kebanyakan guru. Guru matematika menjelaskan, memberi contoh, memberi latiahan dan tugas. Pembelajaran matematika yang kurang memperhatikan proses akan membuat siswa kurang termotivasi rasa ingin tahunya dalam belajar matematika. Hal ini disebabkan proses pembelajaran hanya berpusat pada guru yaitu guru hanya menjelaskan. Siswa hanya duduk pasif mendengarkan dan mengerjakan soal-soal yang di berikan guru. Padahal rasa ingin tahu adalah awal membuka suatu pengetahuan ataupun ide.

ntegrasi potensi lokal dalam pembelajaran mampu menumbuhkan rasa ingin tahu dalam diri peserta didik. Hal tersebut sejalan dengan penelitian yang dilakukan oleh (Ilma \& Wijarini, 2017).Bahwa bahan ajar dengan integrasi potensi lokal dapat meningkatkan rasa ingin tahu dan minat belajar peserta didik terhadap IPA. Integrasi potensi lokal dalam pembelajaran tercantum dalam Undang-Undang Nomor 20 tahun 2003 tentang sistem pendidikan nasional yang menyatakan bahwa kurikulum dalam setiap jenjang dan jenis pendidikan dikembangkan sesuai dengan potensi daerah (Presiden Republik Indonesia, 2003). Integrasi potensi lokal dalam pembelajaran mampu memberikan wawasan kepada peserta didik sehingga mereka mampu mengolah potensi lokal menjadi hal yang lebih bermakna. Potensi lokal yang diintegrasikan dalam penelitian ini yaitu industri gula dari tebu atau pabrik gula Djombang Baru. Pabrik gula merupakan industri yang mengolah tebu menjadi gula kristal putih melalui berbagai proses kimiawi maupun fisika.

\section{METODOLOGI PENELITIAN Desain penelitian}

Penelitian ini menggunakan jenis penelitian survey. Desain penelitian survei merupakan langkah dalam penelitian kuantitatif bahwa peneliti melakukan survei terhadap sampel atau keseluruhan populasi orang untuk menggambarkan sikap, pendapat, perilaku, dan karakteristik suatu populasi.

\section{Sampel penelitian}

Penelitian saya terletak di SMP Negeri 1 Muaro Jambi sekolah ini terletak di Simpang Sungai Duren, Kec. Jambi Luar Kota, Kabupaten Muaro Jambi, Jambi 36657. Disini saya hanya mengambil beberapa orang siswa sekitas 30-40 lebih siswa. Penelitian ini dilakukan dengan tes kusioner yaitu angket dan hasil nilai siswa.

\section{Instrumen dan prosedur penelitian}

Untuk validitas angket digunakan rumus korelasi product moment dikutip dari Arikunto (2013) Sebelum instrumen angket digunakan dalam penelitian terlebih dahulu diuji cobakan kepada responden. Responden yang dipilih dalam uji coba adalah tempat melakukan penelitian, hal ini bertujuan agar kemampuan siswa tidak berbeda jauh dengan kemampuan siswa yang akan diteliti. Pengujian validitas dalam menganalisis hasil uji coba dilakukan dengan menggunakan rumus korelasi product moment. Instrumen angket yang digunakan setelah diseleksi terdiri dari 25 item menggunakan skala Likert dengan alternatif jawaban yang disediakan. Data penelitian yang digunakan data kuantitatif. Teknik pengumpulan data pada penelitian ini berupa angket dan wawancara. Sumber data pada penelitian ini adalah seperempat dari seluruh siswa dan siswi SMP Negeri 1 Muaro Jambi. Jenis angket yang 
digunakan yaitu angket tertutup berupa angket sikap siswa SMA terhadap pelejaran Fisika dalam skala Likert antaranya sangat setuju (SS), setuju (S), tidak setuju (TS), dan sangat tidak setuju (STS) dan pengukuran nilainya dimulai dari 4,3,2,1 dari skala sangat setuju.

\section{Analisis Data}

Yang kita ketahui, statistik deksriptif adalah statistik yang berfungsi untuk mendeksripsikan atau memberi gambaran terhadap obyek yang diteliti melalui data sampel atau populasi sebagaimana adanya tanpa melakukan analisis dan membuat kesimpulan yang berlaku untuk umum. statistika diskriptif (descriptif statistics) yaitu proses pengumpulan dan peringkasan data, serta upaya untuk menggambarkan berbagai karakteriktif yang penting pada data. Dari berbagai pendapat tentang pengertian dan maksud dari statistika deskriptif, dapat disimpulkan bahwa statistika deskriptif yaitu proses pengumpulan dan peringkasan data, serta upaya untuk menggambarkan terhadap obyek yang di teliti melalui data sampel atau populasi sebagaimana adanya.
Pada teknik analisis data Lingkungan Belajar siswa dalam lembar angket. Skor hasil angket jika siswa memilih sangat setuju 4, setuju 3 , tidak setuju 2 sangat tidak setuju 1. Klasifikasi skor berdasarkan jumlah yang di peroleh dapat di hitung menggunakan rumus menurut Widoyoko (2014) sebagai berikut:

$$
\begin{gathered}
\text { Jarak interval }(\mathrm{i})=\frac{\text { skor tertinggi-skor terendah }}{4} \\
4=\frac{140-35}{4}=26,25
\end{gathered}
$$

\section{B. HASIL DAN PEMBAHASAN}

1. Analisis Hasil Angket Karakter Rasa Ingin Tahu pada SMP Negeri 1 Muaro Jambi

Karakter minat membaca yang ditotalkan 44 siswa. Karakter pada minat membaca terdiri atas 30 pertanyaan yang masing-masing diberi skor 14.Uji ini dilakukan untuk mengetahui bagaimana derajat kekuatan hubungan variable independen dengan variable dependen.

Nilai korelasi yang didapat yaitu sebagai berikut:

Tabel 1. Correlations

\begin{tabular}{|l|l|r|r|}
\hline \multicolumn{2}{|c|}{} & angket_minat_belajar & \multicolumn{1}{c|}{ hasil_belajar } \\
\hline \multirow{4}{*}{ angket_minat_belajar } & Pearson Correlation & 1 &, $804^{* *}$ \\
\cline { 2 - 4 } & Sig. (2-tailed) & 44 &, 000 \\
\cline { 2 - 4 } & $\mathrm{N}$ &, $804^{* *}$ & 44 \\
\hline \multirow{3}{*}{ hasil_belajar } & Pearson Correlation &, 000 & 1 \\
\cline { 2 - 4 } & Sig. (2-tailed) & 44 & 44 \\
\cline { 2 - 4 } & $\mathrm{N}$ & & \\
\hline \multirow{2}{*}{$* *$ Correlation is significant at the 0.01 level (2-tailed). }
\end{tabular}

\section{Pembahasan}

Rasa ingin tahu adalah suatu emosi yang berkaitan dengan perilaku ingin tahu seperti eksplorasi, investigasi, dan belajar, terbukti dengan pengamatan pada manusia dan lainnya. Istilah ini juga dapat digunakan untuk menunjukkan perilaku itu sendiri disebabkan oleh emosi rasa ingin tahu. Seperti emosi Rasa ingin tahu merupakan dorongan untuk tahu hal-hal baru, rasa ingin tahu adalah kekuatan pendorong utama di balik penelitian ilmiah dan disiplin ilmu lain dari studi manusia.

Kadang kala manusia mepunyai rasa ingin tau yang tinggi apabila mereka menemukan hal yang baru. Dari lahir sampai meranjak tua manusia masih mempunyai insting keingin tauan yang tinggi. Jadi dengan penelitian ini kami peneliti dan yang akan meneliti karakter rasa ingin tau ini kedepan nya mengetahui apa penyebab rasa ingin tau itu berkurang. Pada saat kita mengetahui penyebab nya kita dapat mengambil tindakan dengan mendorong mulai dari siswa sekolah. Terkadang rasa ingin tau itu muncul pada ajaran yang salah sehingga mereka berfokus pada hal yang salah. Apa yang tampaknya terjadi adalah rasa ingin tahu manusia dikombinasikan dengan kemampuan untuk berpikir secara abstrak, menyebabkan mimesis, fantasi dan imajinasi, 
akhirnya menimbulkan cara unik manusia berfikir yang abstrak dan standar. Rasa ingin tahu mendorong manusia untuk melakukan berbagai kegiatan yang bertujuan untuk mencari jawaban atas berbagai persoalan yang muncul dalam fikiran nya. Apa yang tampaknya terjadi adalah rasa ingin tahu manusia dikombinasikan dengan kemampuan untuk berpikir secara abstrak, menyebabkan mimesis, fantasi dan imajinasi, akhirnya menimbulkan cara unik manusia berpikir.

Dari hasil data penelitian karakter rasa ingin tau yang kita teliti di SMP Negeri 1 Muaro Bungo didapatkan bahwa siswa disana memiliki rasa ingin tau yang tinggi . dari tabel tersebut dapat kita lihat person korelasi nya yaitu ,804 dengan sig ,000 dan $\mathrm{N}$ nya 44. $\mathrm{N}$ yaitu jumlah siswa yang telah di dikorelasi. Dalam wiratna sujarweni,2014, menjelaskan bahwa keeratan hubungan atau koefisien korelasi antar variabel dapat dikelompokkan sebagai berikut:

a. Nilai koefisien korelasi 0,00 sampai 0,20 berarti hubungan sangat lemah.

b. Nilai koefisien korelasi 0,21 sampai 0,40 berarti hubungan lemah.

c. Nilai koefisien korelasi 0,41 sampai 0,70 berarti kuat.

d. Nilai koefisien korelasi 0,71 sampai 0,90 berarti hubungannya sangat kuat.

e. Nilai koefisien korelasi 0,91 sampai 0,99 berarti hubungannya kuat sekali.

f. Nilai koefisien korelasi 1,00 berarti hubungan sempurna

Mengetahui teori tentang dasar pemgambilan keputusan untuk uji normalitas. Adapun dasar pengambilan keputusan dalam uji normalitas adalah sebagai berikut: 1. Jika nilai signifikansi nya (sig) $<0,05$ maka variabel yang didistribusikan normal. 2. Jika nilai signifikansi (sig) >0,05 maka variabel berdistribusi normal. Dalam hal ini dapat kita lihat bahwa tabel diatas nilai yang kita punya pada tabel korelasi yaitu ,804 yang berarti nilai koefisien nya adalah sangat kuat dan pada tabel diatas kita memperoleh sig nya adalah ,000 maka data yang kita signifikansi normal. Dengan demikian asumsi dasar atau persyaratan dalam uji korelasi bivariate sudah terpenuhi yang artinya uji korelasi pada SMP Negeri 1 Muaro Jambi itu normal.

\section{SIMPULAN}

Konsep bahwa sebaiknya 'belajar ditumbuhkan dari rasa ingin tahu' memang sudah saya pelajari berulang kali, tetapi ternyata konsep itu belum sempurna melekat dalam pikiran saya. Pagi ini, ketika saya iseng membuka beberapa blog -tentang Pendidikan- saya menemukan suatu kalimat yang sedikit mencerahkan batin saya. dalam analisis korelasi nya sebenarnya ada istilah variabel independen (x) dan variabel independen (y). Karena pada dasarnya hubungan antara variabel independen dengan variabel independen akan bermakna sama dengan hubungan variabel independen . koefisien korelasi atau pearson correlations memiliki nilai paling kecil -1 dan paling besar 1. Berkenaan dengan besaran angka ini,jika 0 maka artinya ada korelasi sama sekali sementara jika koelasi nya 1 berarti ada korelasi sempurna. Dalam hal ini menujukkan bahwa semakin nilai person correlation nya mendekati -1 atau 1maka hubungan antara dua variabel semakin kuat. Maka sebaliknya jika nilai korelasi nya mendekati 0 berarti 2 hubungan 2 variabel menjadi lemah. Selain besarnya korelasi, tanda korelasi juga berpengaruh pada penafsiran hasil dalam analisa dimana negatif pada SPSS menunjukkan arah berlawanan sedangkan tanda positif menunjukkan arah yang sama atau searah.

\section{UCAPAN TERIMA KASIH}

Dalam penyusunan artikel ini, penulis mendapatkan banyak sekali bantuan dari berbagai pihak. Oleh karena itu saya selaku penulis ingin mengucapkan terimakasih kepada :

1. Bapak Dwi Agus Kurniawan, S.Pd., M.Pd dan Drs. Maison, M.Si. Ph.D selaku dosen pembimbing mata kuliah metode penelitian .

2. Guru di SMP Negeri 12 Kota Jambi telah berbaik hati membatu dalam penelitian ini

3. Serta adik-adik SMP Negeri 12 Kota Jambi.

4. Kakak dan teman-teman serta orang tua yang sudah dengan sepenuh hati memberikan saran, informasi dan juga masukan.

\section{DAFTAR PUSTAKA}

Depdiknas. (2003). Undang-Undang Republik Indonesia Tentang STANDAR PROSES PENDIDIKAN DASAR DAN MENENGAH. 
Depdiknas. (2003). Undang-Undang Republik Indonesia No. 20 Tahun 2003, tentang Sistem Pendidikan Nasional.

Fitri Wijarini, Silfia Ilma.2017. Analisis keterampilan mengajar mahasiswa jurusan pendidikan biologi universitas borneo tarakan sebagai calon guru melalui kegiatan ppl. Jurnal Pendidikan Biologi Indonesia: universitas borneo tarakan.

Ika Maryani, Laila Fatmawati.2018. Pendekatan scientific dalam pembelajaran di sekolah dasar: teori dan praktik. Jurnal pendidikan PGSD: universitas ahmad dahlan.

Juhri. 2006. Landasan dan Wawasan Pendidikan:

Lembaga Penelitian Universitas Muhammadiyah Metro. Metro.
Oemar Hamalik. 2004. Psikologi Belajar dan Mengajar. Bandung: Sinar Baru Algensindo

Sugiyono. 2014. Metode Penelitian Pendidikan Pendekatan Kuantitatif, Kualitatif Dan R\&D. Bandung: Alfabeta

Suardi, Moh. 2012. Pengantar Pendidikan teori dan aplikasi. Kembangan, Jakarta: Barat. PT. Indeks.

Syah, Muhibbin. 1995. Psikologi Pendidikan Suatu Pendekatan Baru. Bandung : Remaja Rosdakarya. 